\title{
Changes in the ecological balance of invertebrate communities in kelp holdfast habitats of some polluted North Sea waters
}

\author{
D. J. JONES \\ Department of Botany, University of Durbam; Durbam City, England
}

\begin{abstract}
KURZFASSUNG: Veränderungen des ökologischen Gleichgewichts von InvertebratenLebensgemeinschaften in Habitaten der Haftorgane von Tangen einiger verunreinigter Nordseegewässer. Die durch Wasserverunreinigungen bedingten räumlichen und zeitlichen Veränderungen der Lebensgemeinschaften von Invertebraten, die auf dem Haftorgan der Braunalge Laminaria byperborea GunN. Foste siedeln, wurden untersucht. Alle Beobachtungen beziehen sich auf die nordöstliche Küste Englands und die südwestliche Küste Schottlands. Die Arbeit schließt sich an eine frühere Veröffentlichung (Jones 1971) an, in der die chemischen, physikalischen und biologischen Faktoren behandelt wurden, welche die verschmutzten Küstengebiete charakterisieren. Dabei wurde unterschieden zwischen der jährlichen Zuwachsrate des Haftorgan-Habitats (gemessen in $\mathrm{mm}^{3}$,ecospace“) und der Besiedlungsrate ("ecoperiod"). Die Ergebnisse zeigen, daß die Entwicklung der Epifauna auf Laminaria hyperborea in einem Radius von ungefähr $50 \mathrm{~km}$ um den Firth of Forth und in einem Bereich von $100 \mathrm{~km}$ in offenen, verschmutzten Küstengewässern verlangsamt ist. In verunreinigten Küstengewässern entsteht eine wenig stabile Nahrungskette, die sich auf Detritus aufbaut. Der periodische Verlust einiger nur kurzfristig siedelnder Arten scheint zu bewirken, daß sich die Biozönose nicht unabhängig von benachbarten, in unverschmutzten Gebieten vorkommenden marinen Gemeinschaften entwickeln kann. Die möglichen Dauerfolgen der Verschmutzung auf derartige neotene Lebensgemeinschaften werden diskutiert.
\end{abstract}

\section{INTRODUCTION}

The seven-year average growth span of a Laminaria byperborea plant provides a holdfast habitat for large numbers of benthic invertebrates associated with sublittoral kelp forests in the North Sea. As the holdfast enlarges with growth, a sequence of invertebrate species colonizes the habitat; it provides and creates a pioneer community composed of few species in a short detritus food chain. The pioneer species in these early communities do not obtain direct sustenance from the plant but seem to select the interstices of the holdfast as a sheltered environment.

In the clean waters, a sequence of invertebrates colonizes the gradually enlarging habitat over its seven-year development period. A "climax" invertebrate community arises which is made up of many species in a complex food web. In polluted waters, the pioneer community is retained through all subsequent stages of holdfast-habitat devel- 
opment, from the first to the seventh year of its growth. The retention of the juvenile component of the community into the mature stages of habitat development was previously described as neotenous community development (Jones 1971).

This paper presents a spatial and temporal study of the neotenous, pollutiontolerant community found in the holdfast habitat of Laminaria byperborea GuNN. FosLE. along the shores of northeast England and southwest Scotland (Fig. 1).

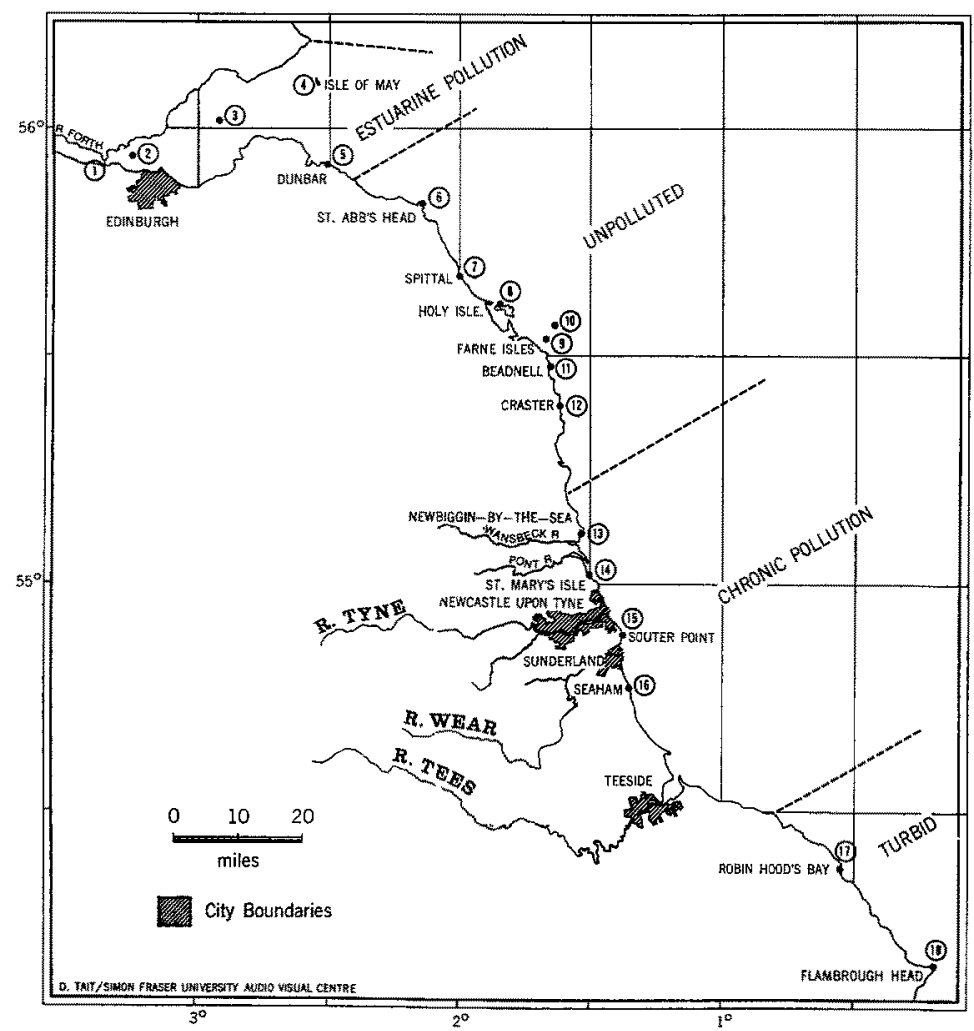

Fig. 1: Northeast pollution gradient showing location of sampling stations

\section{NORTHEAST POLLUTION GRADIENT, LOCA'TION OF SAMPLING STATIONS AND STUDY METHODS}

Chemical, physical and biological parameters used to define and delimit the polluted waters of the study area shown in Figure 1 have been described (BeLLAMY \& WHITtrck 1968, Jones 1971). The following regional differences in coastal-water quality were distinguished: (1) The urbanization and industrial development of the land adjacent to the Firth of Forth has certainly led to pollution of this estuary (Stations 1-4). (2) This estuarine pollution does not extend south to Berwickshire 
where Station 6 (St. Abbs) was established as a clean water reference station in coastal waters having unpolluted oceanic characteristics (Stations 5-13). (3) Proceeding south from Station 6 a gradient of increasing pollution has been demonstrated which reaches its peak along the shores of Co. Durham (Stations 14-16). (4) The coastline south from Scarborough to Flambrough Head is reasonably unpolluted but contains high levels of naturally occurring silt in suspension (Stations 17-18).

Random samples of one- to seven-year old holdfasts of the kelp plant were collected by scuba divers at each station and treated in the laboratory in the manner described by JoNEs (1971). Seven consecutive year classes of the plant provide the seven stages of habitat development measured as "ecospace" volume. Annual "ecoperiods" from one to seven years describe the sequence of succession into the enlarging habitat. The sum of one set of seven successive annual ecoperiods, a complete successional unit, is used here for comparisons between stations along the pollution gradient.

\section{RESULTS}

Species diversity, which can be taken as a measure of maturity and stability (MARGALEF 1968), was consistently greater at the unpolluted stations. Figure 2 presents the MARGALEF Diversity Index "I" calculated for the sum of seven annual ecoperiods at stations along the pollution gradient. A low value for this index indicates that the physical conditions prevailing in the vicinity of the habitat are adverse. Community development is inhibited and this is seen as a decrease in the number of species present although the total number of organisms may increase because of reduced competition. The index is given by the expression $-\mathrm{I}=-\Sigma$ pi $\ln$ pi where $\mathrm{I}$ is the diversity index, $\mathrm{pi}$ is the number of organisms in a species $\mathrm{i}$, divided by the total number of organisms in the sample, and ln pi is the natural logarithm of that fraction. The mean index "I" for the polluted estuary was 2.2 , increasing to 3.4 in the clean waters off Berwick. It was again reduced in the polluted waters of Co. Durham to a mean value of 2.7, recovering to a value of 3.3 in the turbid but unpolluted waters of Yorkshire.

Individual community fluctuations occurred in both polluted and unpolluted study areas. The lowered value of the index at Stations 9 and 10, the Farne Isles, is attributed to the extreme water movements in this area, often in excess of five knots even on a calm summer day. In all other clean water communities, the index rose to a value in excess of 3.0 and fluctuation between 3.0 and 4.3 is considered natural biotic variation. Where values of the index " $\mathrm{I}$ " range from 0.0 to approximately 2.5 the environment was adverse, preventing a high level of species diversification in the habitat. Values of the index about 3.0 indicate a diverse community, the "normal" state in the ecospace habitat.

Figure 3 presents the MARGALEF Diversity Index "I" calculated for the sum of seven successive annual ecoperiods at Station 6 and Station 15 over the 31 months of the study. The mean species diversity in polluted water at Station 15 was 2.9, the mean index for clean water equalled 3.7. The mean annual value of the index was reduced by approximately one half in polluted waters, indicating a persistent lowering in the species complement of the community developed there. 


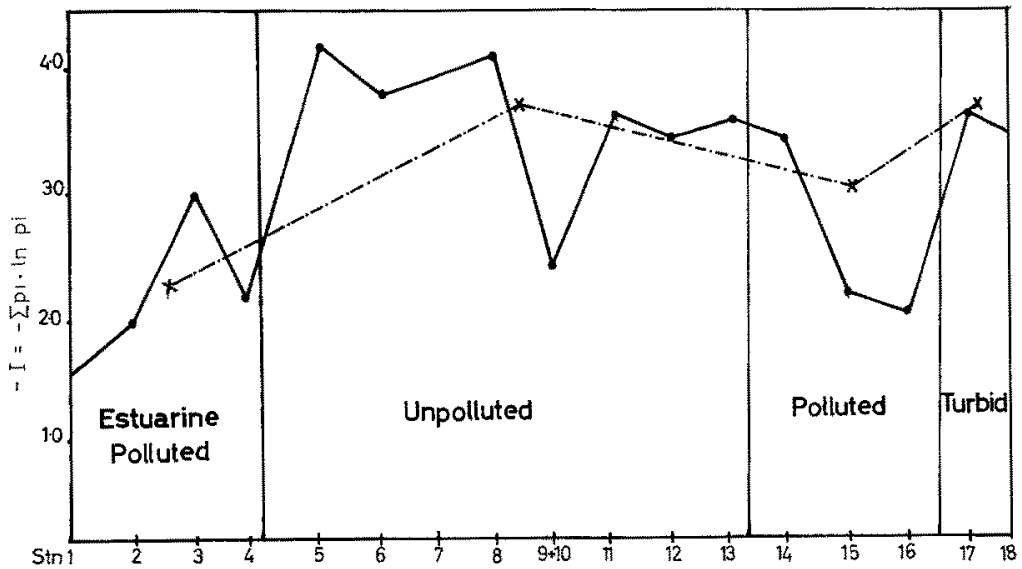

Fig. 2: Spatial comparison of MARGALEF Diversity Index "I" along the pollution gradient

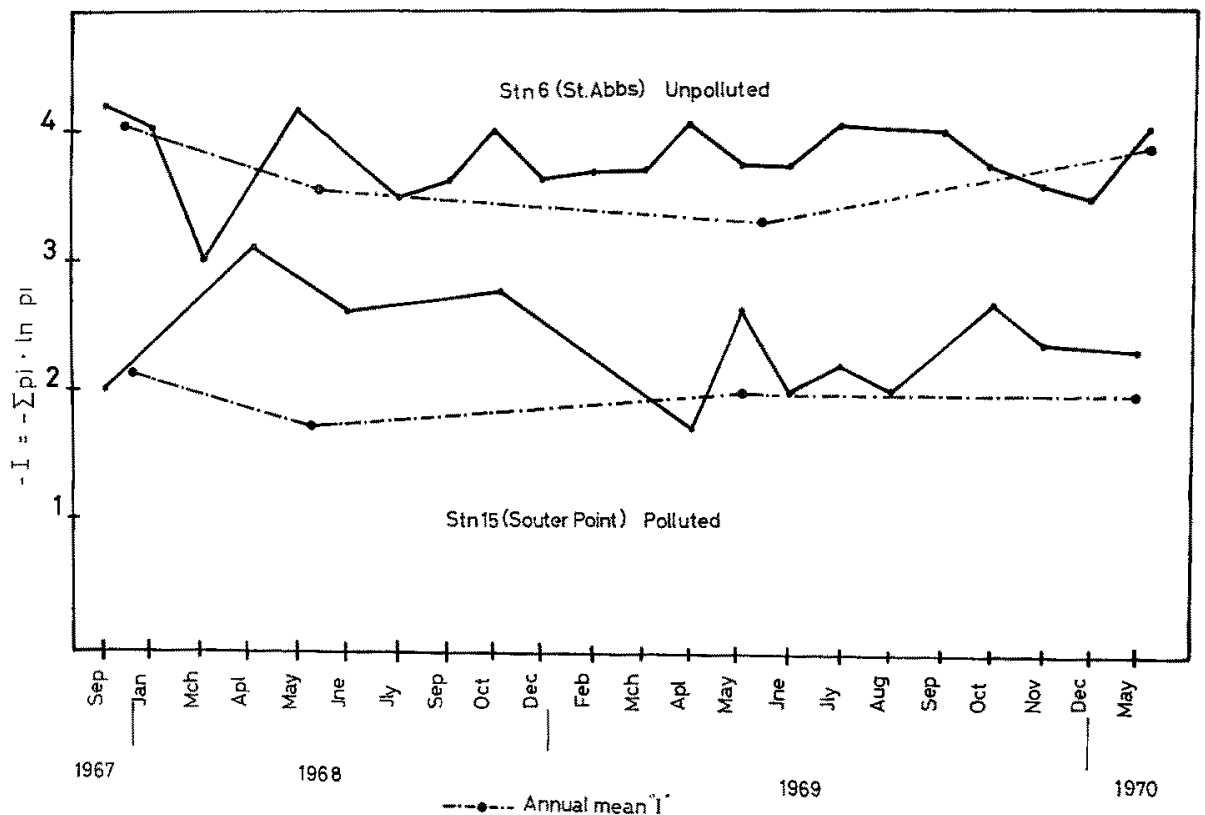

Fig. 3: Temporal comparison of Margalef Diversity Index at Station 6 (unpolluted reference station) and Station 15 (chronically polluted)

As a single numerical index of community diversity, the Margalef Index combines the number of species and the number of individuals within one species with the total number of individuals of all species in the habitat. One disadvantage of this 
Table 1

Succession in one seven-year ecoperiod at Station 6 (unpolluted reference station) and Station 15 (chronically polluted), June 1968

\begin{tabular}{|c|c|c|c|c|c|c|c|c|c|}
\hline $\begin{array}{l}\text { Ecoperiod years } \\
\text { Ecospace CC's }\end{array}$ & $\begin{array}{l}1 \\
0\end{array}$ & $\begin{array}{c}2 \\
1.6 \\
\end{array}$ & $\begin{array}{c}3 \\
10.0 \\
\end{array}$ & $\begin{array}{c}4 \\
36.0 \\
\end{array}$ & $\begin{array}{c}5 \\
92.0 \\
\end{array}$ & $\begin{array}{c}6 \\
181.0 \\
\end{array}$ & $\begin{array}{l}7 \\
313.0 \\
\end{array}$ & $\begin{array}{c}\text { Total } \\
\text { species }\end{array}$ & $\begin{array}{l}\text { Per cent of } \\
\text { community }\end{array}$ \\
\hline \multicolumn{10}{|c|}{ Station 6} \\
\hline Umbonula verrucosa & 1 & 0 & 1 & 1 & 1 & 1 & 1 & 6 & 3.1 \\
\hline Pomatoceros triqueter & & 2 & 0 & 5 & 5 & 6 & 8 & 26 & 13.7 \\
\hline Nereis pelagica & & & 2 & 1 & 2 & 1 & 3 & 9 & 4.7 \\
\hline Mya truncata & & & 1 & 1 & 0 & 1 & 6 & 10 & 5.2 \\
\hline Opbiotbrix fragilis & & & 1 & 4 & 3 & 5 & 16 & 29 & 15.3 \\
\hline Mucronella coccinea & & & 1 & 1 & 1 & 1 & 1 & 5 & 2.6 \\
\hline Lepidonotus squamatus & & & & 1 & 1 & 2 & 3 & 7 & 3.7 \\
\hline Porcellana longicornis & & & & 1 & 1 & 2 & 13 & 17 & 8.9 \\
\hline Opbiopholis aculeata & & & & & 4 & 2 & 6 & 12 & 6.3 \\
\hline Asterias rubens & & & & & 2 & 1 & 11 & 14 & 7.4 \\
\hline Jassa falcata & & & & & 10 & 0 & 1 & 11 & 6.3 \\
\hline Eupagurus bernbardus & & & & & & 1 & 1 & 2 & 1.0 \\
\hline Salmacina dysteri & & & & & & & 1 & 1 & 0.5 \\
\hline Pbyllodoce sp. & & & & & & & 1 & 1 & 0.5 \\
\hline Botryllus schlosseri & & & & & & & 1 & 1 & 0.5 \\
\hline Henricia sanguinolenta & & & & & & & 1 & $i$ & 0.5 \\
\hline Nymphon gracile & & & & & & & 3 & 3 & 1.5 \\
\hline Eçbinus esculentus & & & & & & & 6 & 6 & 3.1 \\
\hline Palaemon squilla & & & & & & & 1 & 1 & 0.5 \\
\hline Monia patelliformis & & & & & 5 & 2 & & 7 & 3.7 \\
\hline Anomia epbippium & & & & & 4 & 1 & & 5 & 2.6 \\
\hline Flabelligera affinis & & & & & 1 & & & 1 & 0.5 \\
\hline Acanthocbitona crinitu & & & & & 1 & & & 1 & 0.5 \\
\hline Buccinum undatum & & & & & 1 & & & 1 & 0.5 \\
\hline Venerupis pullustra & & & & & 1 & & & 1 & 0.5 \\
\hline Galathea squamifera & & & & & & 1 & & 1 & 0.5 \\
\hline Taelia felina & & & & & & 1 & & 1 & 0.5 \\
\hline Tectura testudinalis & & & & & & 1 & & 1 & 0.5 \\
\hline \multirow[t]{2}{*}{$\Sigma$} & & & & & & & & 189 & 100.0 \\
\hline & & & \multicolumn{2}{|c|}{ Station } & 15 & & & & \\
\hline Sabellaria spinulosa & 1 & 2 & 2 & 10 & 25 & 38 & 70 & 148 & 70.4 \\
\hline Patina pellucida & & 1 & & & & & & 1 & 0.4 \\
\hline Asterias rubens & & & 2 & & & 1 & 2 & 5 & 2.3 \\
\hline Amphithoe rubricata & & & 2 & & & & & 2 & 0.9 \\
\hline Nereis pelagica & & & & 1 & 4 & 2 & & 7 & 3.3 \\
\hline Mytilus edulis & & & & 4 & & 4 & 3 & 11 & 5.2 \\
\hline Anomia ephippium & & & & 4 & & & 3 & 7 & 3.3 \\
\hline Nomia patelliformis & & & & 5 & & & 2 & 7 & 3.3 \\
\hline Lepidontus squamatus & & & & 1 & & 1 & 5 & 7 & 3.3 \\
\hline Ophiopholis aculeata & & & & 2 & & & & 2 & 0.9 \\
\hline Taelia felina & & & & 1 & & 1 & & 2 & 0.9 \\
\hline Pomatoceros triqueter & & & & & 1 & & & 1 & 0.4 \\
\hline Mya truncata & & & & & 1 & & 1 & 2 & 0.9 \\
\hline Membranipora membro & racea & & & & & 1 & & 1 & 0.4 \\
\hline Pycnogonium littorale & & & & & & 1 & & 1 & 0.4 \\
\hline Flabelligera affinis & & & & & & 1 & 1 & 2 & 0.9 \\
\hline Acantbochitona crinitu & & & & & & 1 & & 1 & 0.4 \\
\hline Jassa falcata & & & & & & & 1 & 1 & 0.4 \\
\hline Henricia sanguinolenta & & & & & & & 1 & 1 & 0.4 \\
\hline Cancer pagurus & & & & & & & 1 & 1 & 0.4 \\
\hline$\Sigma$ & & & & & & & & 210 & 100.0 \\
\hline
\end{tabular}


Table 2

Succession in one seven-year ecoperiod at Station 6 and Station 15, June 1969

\begin{tabular}{|c|c|c|c|c|c|c|c|c|c|}
\hline $\begin{array}{l}\text { Ecoperiod years } \\
\text { Ecospace CC's }\end{array}$ & $\begin{array}{l}1 \\
0\end{array}$ & $\begin{array}{c}2 \\
1.6\end{array}$ & $\begin{array}{c}3 \\
10.0\end{array}$ & $\begin{array}{l}4 \\
36.0\end{array}$ & $\begin{array}{c}5 \\
92.0\end{array}$ & $\begin{array}{c}6 \\
181.0\end{array}$ & $\begin{array}{l}7 \\
313.0\end{array}$ & $\begin{array}{l}\text { Total } \\
\text { species }\end{array}$ & $\begin{array}{l}\text { Per cent of } \\
\text { community }\end{array}$ \\
\hline \multicolumn{10}{|c|}{ Station 6} \\
\hline Umbonula verrucosa & 1 & 1 & 1 & 1 & 1 & 1 & 1 & 7 & 2.1 \\
\hline Mucronella caccinea & 1 & 0 & 1 & 1 & 1 & 1 & 1 & 6 & 1.8 \\
\hline Ophiopholis aculeata & & 1 & 0 & 1 & 3 & 6 & 2 & 13 & 3.9 \\
\hline Asterias rubens & & 1 & 0 & 2 & 4 & 10 & 7 & 23 & 6.9 \\
\hline Salmacina dysteri & & & 1 & 1 & 1 & 0 & 1 & 4 & 1.2 \\
\hline Pomatoceros triqueter & & & 2 & 0 & 4 & 10 & 5 & 21 & 6.3 \\
\hline Ophiothrix fragilis & & & 1 & 9 & 5 & 7 & 16 & 38 & 11.4 \\
\hline Amphitboe rubricata & & & & 4 & 3 & 3 & 0 & 10 & 3.0 \\
\hline Jassa falcata & & & & 6 & 12 & 10 & 10 & 38 & 11.4 \\
\hline Coropbium bonellii & & & & 2 & 8 & 0 & 10 & 20 & 6.0 \\
\hline Nomia patelliformis & & & & 3 & 0 & 5 & 10 & 18 & 5.4 \\
\hline Anomia ephippium & & & & 5 & 0 & 5 & 2 & 12 & 3.6 \\
\hline Balanus balanus & & & & 2 & & 8 & 2 & 12 & 3.6 \\
\hline Mya truncata & & & & 3 & 2 & 1 & 5 & 11 & 3.3 \\
\hline Porcellana longicornis & & & & 1 & 1 & 8 & 7 & 17 & 5.1 \\
\hline Caprella linearis & & & & & 2 & 6 & 1 & 9 & 2.7 \\
\hline Nereis pelagica & & & & & 5 & 1 & 10 & 16 & 4.8 \\
\hline Lepidontus squamatus & & & & & 4 & 4 & 2 & 10 & 3.0 \\
\hline Hyas areneas & & & & & 1 & 1 & 1 & 3 & 0.9 \\
\hline Pycnogonum littorale & & & & & & 2 & 13 & 15 & 4.5 \\
\hline Cancer pagurus & & & & & & & 1 & 1 & 0.3 \\
\hline Modiolus barbatus & & & & & & & 1 & 1 & 0.3 \\
\hline Henricia sanguinolenta & & & & & & & 1 & 1 & 0.3 \\
\hline Mytilus edulis & & & & 1 & & & & 1 & 0.3 \\
\hline Acantbocbitona crinitus & & & & & 1 & & 1 & 2 & 0.6 \\
\hline Lacuna vincta & & & & & 3 & 5 & & 8 & 2.4 \\
\hline Ecbinus esculentus & & & & & 2 & 3 & & 5 & 1.5 \\
\hline Botryllus schlosseri & & & & & 1 & & & 1 & 0.3 \\
\hline Pbyllodoce sp. & & & & & 1 & 1 & & 2 & 0.6 \\
\hline Membranipora membral & nacea & & & & $i$ & & & 1 & 0.3 \\
\hline Salmacina dysteri & & & & & & 1 & & 1 & 0.3 \\
\hline Alcyonium digitatum & & & & & & 1 & & 1 & 0.3 \\
\hline Nympbon gracile & & & & & & 2 & & 2 & 0.6 \\
\hline Palaemon squilla & & & & & & 1 & & 1 & 0.3 \\
\hline$\Sigma$ & & & & & & & & 332 & 100.0 \\
\hline \multicolumn{10}{|c|}{ Station 15} \\
\hline Mytilus edulis & 4 & 60 & 80 & 200 & 500 & 300 & 200 & 1344 & 94.5 \\
\hline Nereis pelagica & & 1 & 1 & 2 & 4 & 3 & 6 & 17 & 1.1 \\
\hline Asterias rubens & & $i$ & & 1 & & 4 & 1 & 7 & 0.4 \\
\hline Halichondria panacea & & 1 & & 1 & 1 & 1 & & 4 & 0.2 \\
\hline Hymeniacidon perleve & & 1 & & 1 & & & & 2 & 0.1 \\
\hline Lepidonotus squamatus & & & & 1 & & & & 1 & 0.0 \\
\hline Sabellaria spinulosa & & & & 10 & & 10 & 20 & 40 & 2.8 \\
\hline Mya truncata & & & & & 1 & & 3 & 4 & 0.2 \\
\hline Flabelligera affinis & & & & 1 & & & & 1 & 0.0 \\
\hline Cancer pagurus & & & & & & 1 & & 1 & 0.0 \\
\hline Harmatboe impar & & & & & & & 1 & 1 & 0.0 \\
\hline$\Sigma$ & & & & & & & & 1422 & 100.0 \\
\hline
\end{tabular}


calculation is that it obscures much of the information on the kinds of species present and their abundance in the habitat.

Table 1 shows the abundance of individuals and species at all stages of community succession at Station 6 in clean waters and Station 15 in chronically polluted waters. Both samples were collected at the same time. In contrast to the clean-water situation, all stages of the polluted-water habitat contained large numbers of the suspensionfeeding tube worm Sabellaria spinulosa, which finally came to occupy $70.4 \%$ of the species composition in the whole seven year ecoperiod. Other species in the habitat

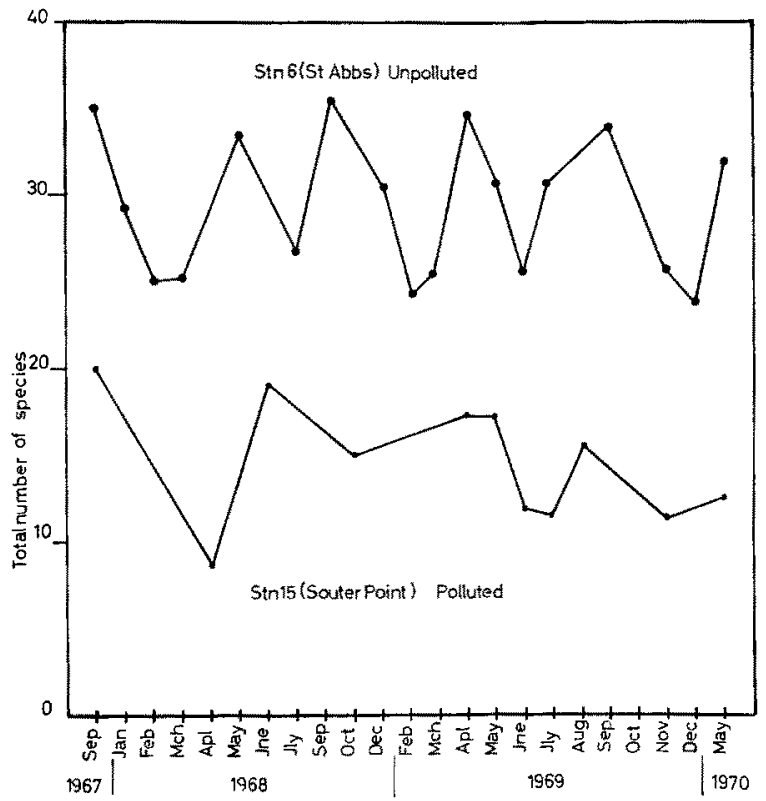

Fig. 4: Variation in the number of species present per complete successional unit at Station 6 (unpolluted reference station) and Station 15 (chronically polluted) during study period

were reduced to insignificant proportions by the single dominant species. The suspension-feeder Mytilus edulis was next in order of dominance, occupying $5.2 \%$ of the community. Two carnivorous species, Asterias rubens and Nereis pelagica, accounted for $2.3 \%$ and $3.3 \%$ of the community.

A similar set of the ecospace habitats was collected 12 months later and is shown in Table 2. The clean-water community had remained essentially unchanged. In the polluted waters at Station 15, a different suspension-feeding species, Mytilus edulis, had replaced the former dominant Sabellaria spinulosa. Large numbers of $M$. edulis filled each annual ecoperiod and dominated other members of the ecospace fauna in all stages of community development. Of the complete community unit, $94.5 \%$ was composed of $M$. edulis. The former dominant $S$. spinulosa had been reduced to only $2.8 \%$ of the community, over the 12-month period.

The size of the ecospace habitat, and the seven annual ecoperiods in the devel- 
opment of the community, remained unchanged at both stations throughout the study (JONEs 1971), but the numbers of species and of individuals colonizing the polluted habitat varied considerably. Variation in the species composition of the polluted communities can be shown by using the total number of species and the total number of individuals of each species in seven annual ecoperiods as separate indices of diversity.

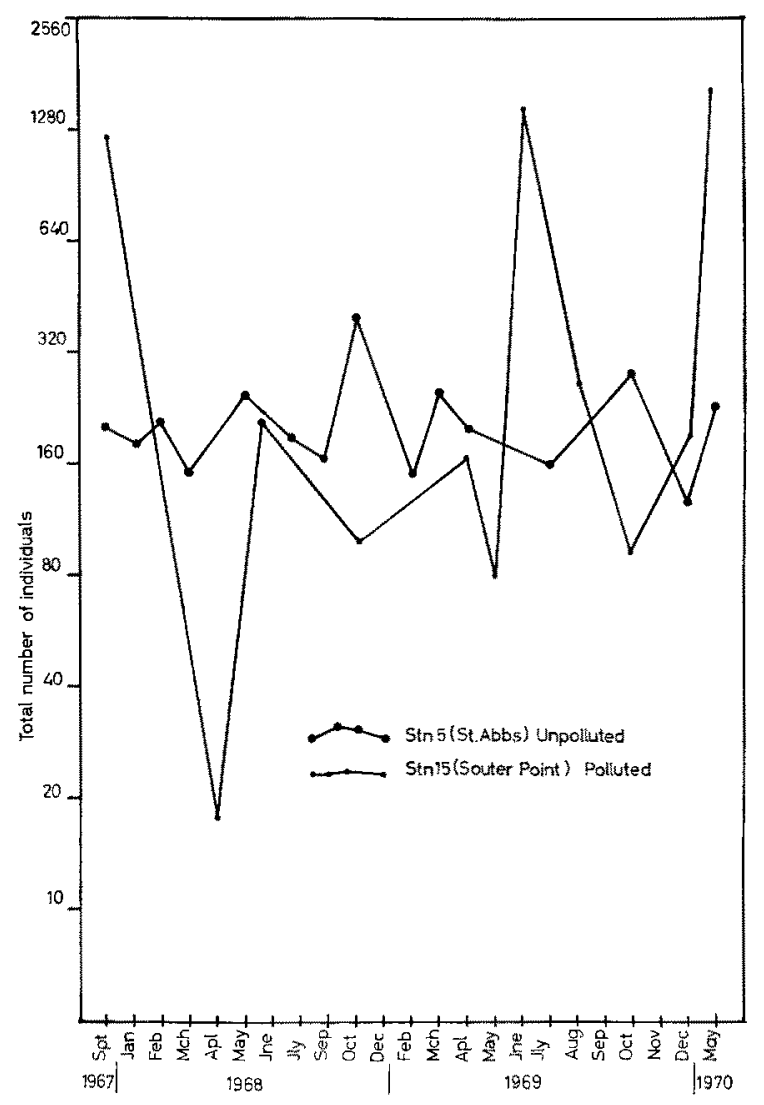

Fig. 5: Variation in the total number of individuals present per complete successional unit at Station 6 (unpolluted reference station) and Station 15 (chronically polluted) during study period

Figure 4 presents variation in the number of species present in St. Abbs (unpolluted reference point), and at Souter Pt. (polluted reference station), during the study. The number of species in clean water was persistently higher than in polluted waters. About half the clean-water species were absent in the polluted areas.

Figure 5 shows the total number of individuals of all species present in the two habitats for the duration of this study. The amplitude of fluctuation in individual numbers was greater in polluted waters. In all, four large fluctuations occurred at Station 15, involving the loss or gain of approximately 1,000 individuals. At Station 6 
a smaller population (but containing more species) underwent six smaller fluctuations involving a loss or gain of approximately 278 individuals. These smaller fluctuations were more frequent than the larger population disturbances in polluted waters. In the latter habitat, population fluctuations corresponded with the arrival of one or other of two suspension-feeding species, Mytilus edulis and Sabellaria spinulosa.

Table 3

Relative abundance of species per one complete successional unit (sum of seven annual ecoperiods) at Station 15 (Souter Point)

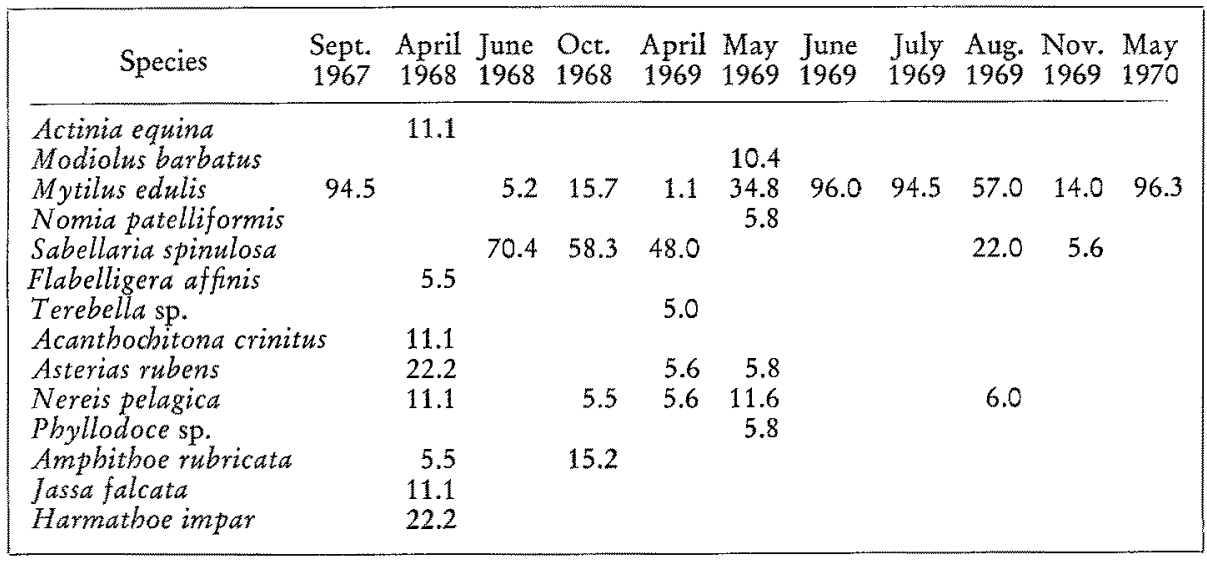

In polluted waters the dynamics of these co-dominant species had major effects on community structure. Table 3 presents the invertebrate species occurring as more than $5 \%$ of the species complement in the community after its development over seven ecoperiods at Station 15 (chronically polluted), for the 31 -month study period. The impoverished community in polluted waters contained a greater proportion of species which were able to withstand pollutants in the water. Of these, Mytilus edulis, Sabellaria spinulosa, Nereis pelagica and Asterias rubens were the new polluted water dominants. Combinations of these species remained dominant throughout the study period. The species Actinea equina, Modiolus barbatus, Flabelligera affinis, Terebella sp., Acanthochitona crinitus, Pbyllodoce sp., Jassa falcata, Harmothoe impar and Amphitboe rubricata occurred occasionally, and sporadically above the $5 \%$ level of abundance in the habitat, but never in great numbers.

When the numbers of Mytilus edulis were high at Station 15, the numbers of Sabellaria spinulosa were low. Each species was dominant for a short period before being replaced by the other, as shown in Figure 6.

In spring 1968 , the polluted waters were not dominated by suspension feeders for a short time. The residual community elements, Flabelligera affinis, Acantbocbitona crinitus, Amphithoe rubricata, Jassa falcata and Harmothoe impar, assumed a dominant role in their absence, but their total numbers in the habitat amounted to only 18 individuals. The residual fauna did not remain dominant for more than a few weeks because of the rapid recolonization of the habitat by a single-species population of the 
suspension feeder, Sabellaria spinulosa. A drop in the numbers of either dominant species effectively "emptied" the habitat, leaving it available for the next spatfall of a single species, which later filled it to capacity.

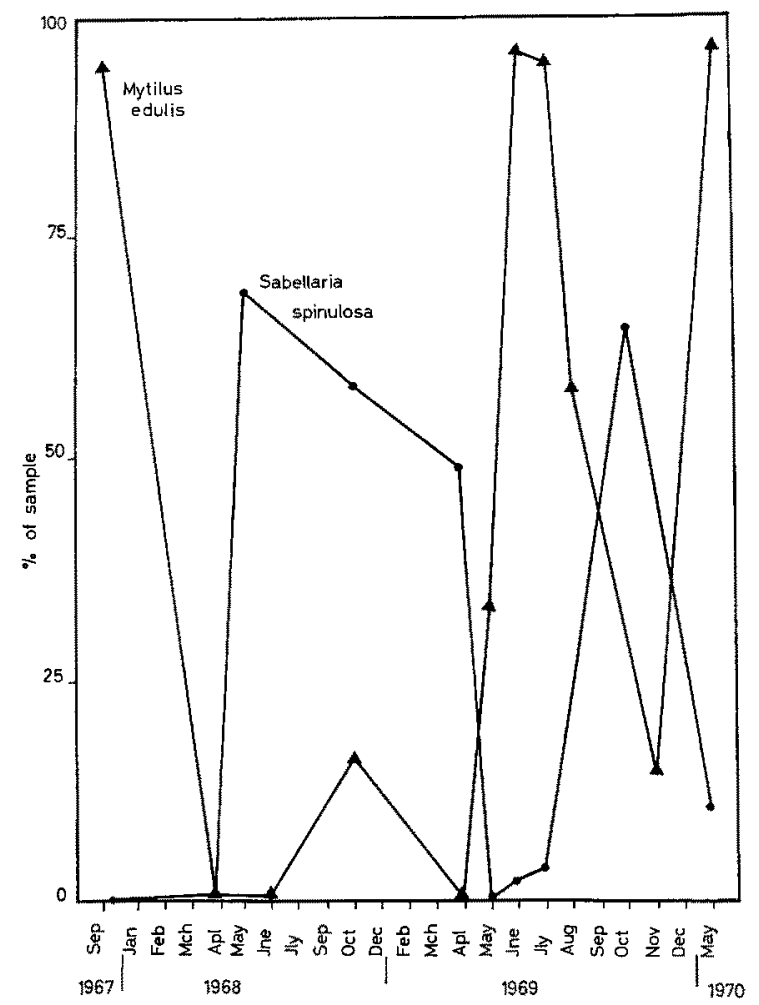

Fig. 6: Fluctuations in the abundance of two dominant suspension feeders at Station 15 (chronically polluted)

Small numbers of the predators Nereis pelagica and Asterias rubens were found at all times in the habitat, but no correlation between the abundance of suspension feeders and predators was observed.

\section{CONCLUSIONS}

Mytilus edulis, Asterias rubens, Nereis pelagica and Sabellaria spinulosa were the most abundant species in the polluted habitat, with only a few other species appearing with these dominants. Values of the Margalef Diversity Index below 2.5 correspond with the absence of many species in polluted waters. Roughly 60 miles of open coastal waters along the shores of Co. Durham and 30 miles of the Forth Estuary are affected in this way. 
The paucity of species in polluted habitats remained a feature of those areas for the duration of the study. The disintegration of the complex food web by the loss of many food chains has entirely removed some energy pathways (Jones 1972). Amongst the remaining fauna, the components of only one detritus food chain persisted in the habitat for any length of time. This was:

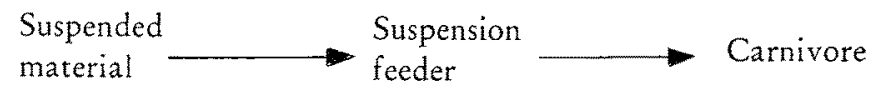

The species involved in this system were:

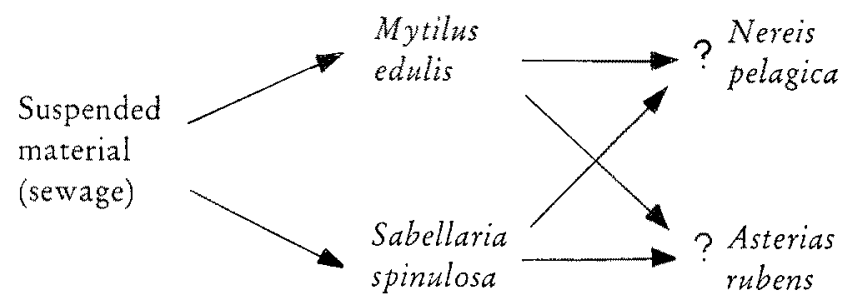

Suspensions of sewage are an abundant available food source for the two suspension feeders, Mytilus edulis and Sabellaria spinulosa, the only predators present being Nereis pelagica and Asterias rubens. The suspension feeders co-dominate in the habitat but never co-exist, so that energy flow to the suspension feeder can only proceed through one species at a time. This simple system is not in balance, and the dynamics of the last remaining fragment of a functional food web warrants further discussion.

Extensive research by SEED (1969a, b), BAYNe (1963, 1964, 1964a, 1965) and Wirson (1968a, b, 1970a, b, 1971) has shown that both Mytilus edulis and Sabellaria spinulosa produce planktonic larvae which preferentially select their place of final settlement by extending their planktonic phases for many weeks. During this time, the larvae can be moved many miles in the sea. The pronounced north-south current drift along these shores makes such larval transport highly likely in this case. Larvae capable of surviving in polluted waters could delay settlement until borne away from the polluted areas on the current drif. However, characteristically large numbers of Sabellaria spinulosa and Mytilus edulis in the polluted habitats indicate that these species are able to colonize polluted waters in much greater numbers than in clean waters (cf. MnLeikovsky 1970). There was no detectable recruitment of a single species in the clean waters on such a scale. Within months of settlement, the new population numbers declined sharply. Each new settlement of larvae roughly corresponded with the arrival of spring or autumn. Their success in colonizing the habitat seemed to depend on the absence of previously settled larvae of the competing suspension-feeder species.

The cause for the rapid turnover of these species was not determined. It could be the result of the natural imbalance in such a simplified system (LEvens 1962, 1963, Margalef 1967, Odum 1967), or else some direct effect of pollutants which was not determined in this study. Predation on large colonies of single species can drastically reduce its numbers. Mytilus edulis can form a large part of the diet of Asterias rubens. 
SEED (1969b) describes "carpets" of A. rubens on lower littoral shores in autumn, decimating $M$. edulis populations which settled there in spring. He concludes that predation must be even more significant on the sublittoral populations. But the detailed feeding habits of Nereis pelagica are uncertain and WILson (1971) found no predators of Sabellaria spinulosa. Further investigation of the dynamics of predator populations may provide the explanation for the rapid loss of the suspension-feeding groups in polluted waters.

In the neotenous community, the rapid turnover of the suspension feeding populations prevents the development of mature individuals of either species in the habitat. The average life span of a Sabellaria spinulosa individual has been estimated at 8 years (D. P. Wruson, personal communication), but the development time to sexual maturity is uncertain. SEED (1969) has shown that Mytilus edulis takes one year to reach sexual maturity and can live for upwards of twenty years on the open coast (R. SEED, personal communication). This would make the polluted community incapable of functioning independently of breeding stocks located outside the chronically polluted areas.

On the northeast shores included in this study, coastal pollution seems restricted to regions corresponding with intensive industrial and urban use of the adjoining land. If the volume and concentration of pollutants is reduced, then polluted areas should be able to begin recovery by recruiting species from the nursery grounds in the reservoir areas, for use in the reconstruction of the food web (DEAN \& HASKIN 1964, NoRTH et al. 1965, RetsH 1965, 1971). On the northeast coast, a reservoir of pollution-sensitive species can still be found along some of the shoreline of Northumberland and Berwickshire, and its continued presence there will ensure a potential for recovery in the polluted areas to the north and south. Alternatively, if more pollutants are added to existing polluted areas, it could seriously disturb the already precarious equilibrium of the neotenous community developed there. This could result in a final breakdown of the remaining functional food chains and allow an uncontrolled spread of pollutants from existing infalls.

\section{SUMMARY}

1. This paper presents a thirty-one month study of a neotenous invertebrate community which developed in Laminaria byperborea holdfasts in some polluted waters of the North Sea (northeast England und southwest Scotland).

2. Sixty miles of open coastal waters and approximately thirty miles of the Forth Estuary are affected by pollutants.

3. Reduction in the species diversity leaves only one possible detritus food chain in the habitat.

4. This simple community is not in balance.

5. The ecology of the polluted water community is considered and the possible longterm effects of pollution in the kelp forest are discussed.

Acknowledgements. I wish to express my thanks to Dr. D. J. Bellamy who supervised this study. This work was conducted in fulfilment of the $\mathrm{Ph}$. $\mathrm{D}$. requirement at Durham University and financed by a Durham Research Studentship. Mr. E. WALKER, my diving assistant, was financed by an N.E.R.C. grant. This work forms part of the I.B.P. programme (Productivity Marine). 


\section{LITERATURE CITED}

BAyne, B. L., 1963. Responses of Mytilus edulis to increases in hydrostatic pressure. Nature, Lond. 198, 406-407.

- 1964a. Primary and secondary settlement in Mytilus edulis (L.). J. Anim. Ecol. 33, 513-523.

- 1964b. The response of the larvae of Mytilus edulis to light and gravity. Oikos 15, 162-174.

- 1965. Growth and delay of metamorphosis of the larvae of Mytilus edulis (L.). Ophelia 2, $1-47$.

Berlamy, D. J. \& WhitTick, A., 1968. Problems in the assessment of the effects of pollution on inshore marine ecosystems dominated by attached macrophytes. Field Studies Council Publ. Suppl. to Vol. 2.

DeAn, D. \& Haskin, H. H., 1964. Benthic repopulation of the Raritan River estuary following pollution abatement. Limnol. Oceanogr. 9, 551-563.

JONES, D. J., 1971. Ecological studies on macroinvertebrate communities associated with polluted kelp forests in the North Sea. Helgoländer wiss. Meeresunters. 22, 417-441.

- 1972. Variation in the trophic structure and species composition of some invertebrate communities in polluted kelp beds in the North Sea. (In press).

Levins, R., 1962. Theory of fitness in a heterogeneous environment. P. 1. Am. Nat. 96, 361-375.

- 1963. Theory of fitness in a heterogeneous environment. P. 2. Am. Nat. 97, 75-89.

Margalef, R., 1967. The food web in the pelagic environment. Helgoländer wiss. Meeresunters. 18, 548-559.

- 1968. Perspectives in ecological theory. University of Chicago Press, Chicago.

Mrxeik ovsxy, S. A., 1970. The influence of pollution on pelagic larvae of bottom invertebrates in marine near shore and estuarine waters. Mar. Biol. 6, 350-356.

North, W. J., Neushul, M. \& Glendenning, K., 1965. Successive biological changes observed in a marine cove exposed to a large spillage of mineral oil. Symp. Commn. int. explor. scient. Mer. Méditerr. Monaco, 355-361.

Odum, H. T., 1967. Biological circuits and the marine systems of Texas. In: Pollution and Marine Ecology. Ed. by Ol.son, T. A. \& Burgess, F. J. Wiley, New York, 99-157.

Rexsi, D. J., 1965. The effects of oil refinery wastes on benthic marine animals in Los Angeles Harbour, California. In: Symp. Commn. int. Explor. scient. Mer. Méditerr. Monaco, 355-361.

- 1971. Effect of pollution abatement in Los Angeles harbours. Mar. Poll. Bull. 2, 71-74.

SEED, R., 1969a. The ecology of Mytilus edulis (L.) on exposed rocky shores. I. Breeding and settlement. Oecologia 3, 317-350.

- 1969b. The ecology of Mytilus edulis L. (Lamellibranchiata) on exposed rocky shores. II. Growth and mortality. Oecologia 3, 317-350.

Wruson, D. P., 1968a. Some aspects of the development of eggs and larvae of Sabellaria alveolata (L.). J. mar. biol. Ass. U.K. 48, 367-385.

- 1968b. The settlement behaviour of the larvae of Sabellaria alveolata (L.). J. mar. biol. Ass. U.K. 48, 387-435.

- 1970a. Additional observations on the larval growth and settlement of Sabellaria alveolata. J. mar. biol. Ass. U.K. 50, 1-31.

- 1970b. The larvae of Sabellaria spinulosa and their settlement behaviour. J. mar. biol. Ass. U.K. 50, 33-52.

- 1971. Sabellaria colonies at Duckpool North Cornwall. 1961-1970. J. mar. biol. Ass. U.K. 51, 509-581.

Author's address: Dr. D. J. Jones

Department of Biological Sciences

Simon Fraser University

Burnaby 2, B.C.

Canada 